\title{
ע Onko Etelä-Pohjanmaan murteessa rautakautisia jälkiä?
}

\author{
Harri Mantila ja Matti Leivisk
}

\section{Johdanto}

Esihistoriallisen ajan päättyessä eli rautakauden lopulla nykyisen Suomen vauraimmat ja ilmeisesti myös tiheimmin asutut alueet olivat Varsinais-Suomessa, SatakuntaHämeessä, Laatokan Karjalassa ja Savossa Mikkelin seudulla. Näiden lisäksi EteläPohjanmaalla Kyrönjokisuu, nykyisen Isonkyrön, Vähänkyrön, Laihian ja Vöyrin alue, muodostui kansainvaellusajalla (v. 400-60o jKr.) kukoistavaksi keskukseksi, joka kuitenkin köyhtyi ja mahdollisesti jopa autioitui viikinkiajan (noin v. 80o-110o jKr.) alkupuolella. (Lehtosalo-Hilander 1985: 311; Huurre 1995: 168.)

Kyrön rikkaan rautakautisen kulttuurin häviäminen on ollut yksi Suomen esihistorian suurista arvoituksista. Vanhemmassa tutkimuksessa uskottiin, että EteläPohjanmaa autioitui kokonaan viikinkiajan kuluessa, minkä jälkeen Ylä-Satakunnasta ja Hämeestä tulleet eränkävijät asuttivat alueen uudelleen 100o-luvulta lähtien. Tämä on ollut vakiintunut ja laajasti niin arkeologien, historioitsijoiden kuin fennistienkin hyväksymä näkemys 1900-luvun alkupuolelta asti. Myös alueen murretta on kommentoitu siten, että se selittyy hämäläisten ja lounaisten murteiden pohjalta ja että alueella aiemmin puhuttu kielimuoto olisi hävinnyt vanhan asutuksen mukana. (Meinander 1950: 151-152; Luukko 1950: 5, 40-41; T. Itkonen 1972: 86.)

Suomen läntisten murteiden katsotaan yleisesti polveutuvan Varsinais-Suomen ja Satakunta-Hämeen rautakautisten asutuskeskusten murteista eli pohjoiskantasuomesta. Todisteena tästä ovat lukuisat yhteiset länsimurteiset piirteet (T. Itkonen 1972: 86; pohjoiskantasuomen oletuksesta ks. 1983: 217-226; 1984: 355-359; Kallio 2014: 160-163). Itämurteet ja karjala puolestaan polveutuvat itäkantasuomesta, mutta myös niiden synnyssä on mukana vahva läntinen komponentti. Savolaismurteiden lähtökohtana pidetään Mikkelin seudun rautakautista asutusta, joka on arkeologien mukaan jatkoa Laatokan luoteisrantojen muinaiskarjalaiselle asutukselle. Mikkelin seudun löydöissä on havaittavissa kuitenkin myös selvä hämäläinen komponentti, joten savolaismurteiden muotoutumiseen on vaikuttanut myös muinaishämäläinen aines. (T. Itkonen 1983: 199, 222; 1984: 347-57; Leskinen 1999: 361-364; ks. myös Sammallahti 1977: 130-133.)

Jos suomen eteläpohjalaiset murteet nykymuodossaan periytyvät kokonaan Varsinais-Suomen ja Hämeen 1200- ja 1300-lukujen kielimuodosta (ks. T. Itkonen 
1972: 86, 96-97), on erikoista, että Etelä-Pohjanmaalla esiintyy arkaismeja, joita ei tunneta lounais- eikä hämäläismurteista mutta jotka saattavat kyllä esiintyä esimerkiksi savolaismurteissa ja karjalassa. Arkaismien lisäksi murteessa tavataan monia erikoiskehittymiä, jotka ovat vieraita muille murteillemme. Tässä artikkelissa pohdimme, olisiko Etelä-Pohjanmaan murteessa siis havaittavissa jälkiä, jotka palautuisivat jo alueen rautakautiseen asutuskerrostumaan. Kielitieteellisessä kirjallisuudessa tätä ei ole juurikaan pohdittu, koska arkeologien näkemys autiosta viikinkiajasta on ollut niin ehdoton, ja niinpä alueen kielellisen ominaislaadun on ajateltu olevan myöhemmin kehittynyttä. (Leskinen 1999: 362; Lehtinen 2007: 246; ks. myös Leiviskä 2015: 10-12.)

Uusimpien arkeologisten näkemysten mukaan Etelä-Pohjanmaan asutus on kuitenkin mahdollisesti säilynyt läpi koko rautakauden. Se on vain muuttanut olemustaan ratkaisevasti siten, että vanhemman ja keskisen rautakauden (v. 1-799 jKr.) tiheä keskus on hiipunut viikinkiajalla (noin v. $800-1100$ jKr.) ja alue on muuttunut harvaan asutuksi ja köyhtyneeksi periferiaksi, jonne Hämeestä ja Ylä-Satakunnasta on kohdistunut uutta muuttoliikettä. Katkokset arkeologisissa löydöissä kertovat hautaustavoissa, varallisuudessa ja kaupankäynnissä tapahtuneista muutoksista, eivät asutuksen häviämisestä. Asutuksen painopiste on vain mahdollisesti siirtynyt pois aiemmilta rautakautisilta keskusalueiltaan. Nämä eivät enää muun muassa soistumisen ja maankohoamisen vuoksi olleet kelvollisia asutukselle, jolle rantaniityt olivat karjanhoidon vuoksi tärkeitä. Täydellinen autioituminen olisi sen sijaan epätodennäköistä ja varsin poikkeuksellistakin. Asutuksen siirtyminen maankohoamisen seurauksena on muutoinkin tyypillistä Pohjanlahden rannikon asutushistorialle kautta koko esihistorian. (Kuusela 2013: 6; Kuusela, Tiilikkala, Vaske \& Okkonen 2011: 188-190; Raninen \& Wessman 2015: 299, 307-308; Leiviskä 2015: 10-12.)

Jo 180o-luvulta saakka on ollut selvää, että Etelä-Pohjanmaan murre on hyvin varhain eronnut muinaishämäläisestä tai pohjoiskantasuomalaisesta kannasta ja että siinä vaiheessa myöskään ero itäisten ja läntisten murteiden välillä ei ole ollut niin suuri kuin nykyään (Aminoff 1871: 3; ks. myös Laurosela 1913: Xv). Edellä mainittujen uusien EteläPohjanmaan esihistoriaa koskevien arkeologisten tutkimustulosten valossa on tarpeen ottaa tarkasteluun alueen murteen erikoislaatuiset piirteet ja pohtia, mitä ne mahdollisesti kertovat murteen syntyprosessista ja onko murteessa mahdollista nähdä rautakautista kerrostumaa. Erityisen mielenkiintoisia tästä näkökulmasta ovat juuri ne arkaismit, joita ei tavata hämäläis- ja lounaismurteissa mutta joita esiintyy kyllä muissa suomen murteissa ja kauempana itämerensuomalaisella kielialueella. Lounaismurteita keskeisemmässä asemassa tässä ovat hämäläismurteet, joiden katsotaan jatkavan puhtaimmin vanhaa pohjoiskantasuomalaista linjaa. Lounaismurteet puolestaan ovat muuttuneet erityisesti merentakaisten kontaktien seurauksena, ja niiden yhteydet Hämeeseen ovat katkenneet jo ennen vanhemman rautakauden loppua. (T. Itkonen 1972: 86.)

Aminoffista (1871; ks. myös Laurosela 1913: XIV-XV) lähtien Etelä-Pohjanmaan murteen arkaistisiksi ja muille läntisille murteille vieraiksi piirteiksi on mainittu seuraavat:

1) $s n A \sim h n A$-päätteiset inessiivimuodot, esim. mihinä, kärehnäni 'missä, kädessänsä' (Aminoff 1871: 3), 
2) monikon 1. ja 2. persoonan alkuperäiset imperfektimuodot, esim. me ottima, te ottia, ja erityisesti saita-tyyppiset monikon 2. persoonan imperfektimuodot, joissa esiintyy alkuperäinen vahva-asteinen mutta yksinäis-t:llinen persoonapääte (vrt. heikkoasteiset saija, tulija, 'saitte, tulitte'; mts. 2; Laurosela 1913: Xv),

3) *eh- ja *ek-nominien taivutuksen säilyminen erillään ja edustuminen es- ja et-

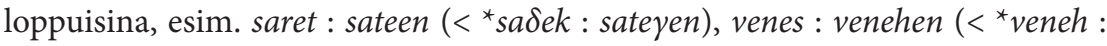
venehen; Aminoff 1871: 3, 9-10, 36),

4) $t t U$ - ja $n U t$-partisiippien muodot, jotka ovat tyyppiä ottanuen, otettuen (otta-

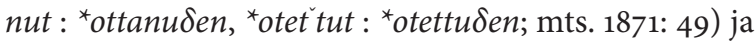

5) aktiivin partisiipin perfektin ja Ut-loppuisten nominien monikkovartaloiset muodot tyyppiä kuollusia ${ }^{*}{ }^{*}$ koollusi $\left.\delta a\right)$ ja neittysillen ( $<{ }^{\star}$ nei $99 y$ sillen; mts. 1871: $16,37)$, joissa näkyy muutos ${ }^{\star} t i>s i$ alkuperäisessä asemassa.

Tarkastelemme tässä artikkelissa näitä jo Aminoffin (1871) mainitsemia arkaismeja ja etenemme seuraavasti: Luvussa 2 kartoitamme ensin kyseisten piirteiden maantieteellisen levikin suomessa ja osin itämerensuomessakin, sitten tarkastelemme piirteiden historiaa ja mahdollista myöhäiskantasuomalaista rekonstruktiopolkua ja lopuksi kokoamme havainnot yhteen. Luvussa 3 vertaamme näitä havaintoja arkeologian viimeaikaisimpiin käsityksiin rautakauden lopun asutus- ja väestöliikkeistä. Näin pyrimme valottamaan Etelä-Pohjanmaan murteen asemaa rautakautisten muinaismurteidemme joukossa. Tarkastelemme myös kahta murteen erikoispiirrettä, joita ei nykymuodossaan ehkä voida pitää arkaismeina mutta jotka muuten valaissevat murrealueen erilliskehityksen ikäkysymystä. Ensimmäinen on ee:n labiaalistuminen 3. persoonan verbinmuodoissa (esim. tuloo). Piirre tunnetaan itämurteissa, karjalassa ja vepsässä. (Ks. mts. 2, 6-7.) Toiseksi pohdimme sitä, miksi Etelä-Pohjanmaalla, kuten kaikissa pohjalaismurteissa ja vanhastaan laajasti savolaismurteissa, karjalassa, vepsässä ja inkeroisessakin, esiintyy verbintaivutuksen monikon 1. ja 2. persoonassa $A$-loppuinen persoonapääte, mutta hämäläis- ja lounaismurteissa vastaavat päätteet ovat $e$-loppuisia (ks. esim. Kettunen 1940: kartta 164; Laanest 1975: 149).

\section{Tarkasteltavien piirteiden levikki ja historia}

Etelä-Pohjanmaan murteen arkaistisista piirteistä ehkä kaikkein erikoisin on inessiivin pääte $h n A \sim s n A$. Sitä ei esiinny lainkaan muissa suomen murteissa, ja koko itämerensuomalaisella kielialueellakin se tunnetaan vain etelävirosta. Pääte $s n A$ vastaa vähintään myöhäiskantasuomen rekonstruktiotasoa, mutta päätteen on katsottu syntyneen jo suomalais-volgalaisessa kantakielessä (ks. esim. Hakulinen 1979: 103). Geminaatta$s: l l i n e n$ inessiivin pääte $s s A$ on helppo selittää $s n A$-päätteen assimiloituneeksi jatkajaksi, mutta epäselvää on, miten yksinäis-s:llinen $s A$-pääte on kehittynyt (Rapola 1966: 243-244; Laanest 1975: 103-104). Pääte $h n A \sim s n A$ esiintyy Etelä-Pohjanmaalla vain pronominivartaloissa jo-, mi-, $k e$ - ja $k u$ - sekä possessiivisuffiksin edellä, esimerkiksi johona, tuvahnani; muutoin murteessa käytetään loppuheittoista $s$-inessiiviä, esimerkiksi täs kyläs. Lauroselan mukaan $h n A$ on vanhempi asu, ja $s n A$-päätteen $s$ on tulosta 
muutoksesta $h>s$, joka on murteessa tapahtunut tämän lisäksi es-nomineissa, esimerkiksi veneh > venes. (Laurosela 1913: 141-146.) Murteen sisäisesti tarkasteltuna $h n A \sim$ $s n A$-inessiivi on joka tapauksessa relikti, joka on säilynyt muutamissa konteksteissa, kun loppuheittoinen $s$-inessiivi on muutoin vallannut alaa.

$h n A \sim s n A$-inessiivistä ei ole mitään jälkiä lounais- eikä hämäläismurteissa. Jos piirteen lähtökohtaa pitäisi hakea yhteisestä pohjoiskantasuomalaisesta kielimuodosta, olisi hämäläismurteiden geminaatallinen $s s A$-pääte helposti palautettavissa assimilaatiokehityksen kautta $s n A$-asuun. Lounaismurteet ovat kuitenkin eri kannalla. Siellä on käytössä loppuheittoinen $s$-inessiivi, kuten siis myös Etelä-Pohjanmaalla, mutta edellä mainituissa pronominivartaloissa ja possessiivisuffiksin etisissä tapauksissa on käytössä sA-pääte (Ojansuu 1903: 90-91), mikä kertonee lounaismurteen edustuksen ennen kuin loppuheittokehitys on kadottanut päätteen loppuvokaalin. Yhteistä pohjoiskantasuomalaista lähtömuotoa on siis vaikea rekonstruoida. Etelä-Pohjanmaan loppuheittoisen inessiivin päätteen Rapola (1966: 243) esittää lainautuneen Satakunnasta.

Monikon 1. ja 2. persoonan geminaatattomat imperfektimuodot, esimerkiksi ottima, saima; otti(j)a, saita saija, edustavat alkuperäistä myöhäiskantasuomalaista asua. Preesensmuotojen geminaatallisissa päätteissä $m m A$ ja $t t A$ on mukana assimiloitunut preesensin tunnus ${ }^{\star} k$, esimerkiksi ${ }^{\star} \operatorname{otakma}(k),{ }^{*}$ otakta $(k)>$ otamma, otatta. Suurimmassa osassa itämerensuomalaisia kielimuotoja tämä preesensin malli on synnyttänyt myös imperfektiin geminaatalliset persoonapäätteet $m m A$, $t$ A . Monikon 2. persoonan alkuperäisellä yksinäis-t:llisellä $t A$-päätteellä ajatellaan olleen suffiksaalisen astevaihtelun mukainen heikkoasteinen pääte ${ }^{\star} \delta A(k)$, joka esiintyi painottoman tavun jäljessä. Näin otti(j)a-tyyppiset muodot edustaisivat alkuperäistä äännelaillista kantaa ja saija-tyyppisissä muodoissa olisi kyse heikkoasteisen päätteen analogisesta yleistymisestä painollisen tavun jälkeiseen asemaan. (Rapola 1966: 143; Laanest 1975: 149; Hakulinen 1979: 250.)

Alkuperäisiä geminaatattomia monikon 1. persoonan imperfektin muotoja tavataan suomen kielessä vain Etelä-Pohjanmaalla ja harvinaisina Oulun seudun murteessa (Laurosela 1913: XV, xxI; Pääkkönen 1971: 176-177). Tämän lisäksi ne ovat tunnettuja karjalassa (Laanest 1975: 149; Bubrih, Beljakov \& Punžina 1997: kartta 144). Monikon 2. persoonan saija, otti(j)a -tyyppisten muotojen levikki on sen sijaan laajempi. Niitä esiintyy laajalti savolaismurteissa ja karjalan kielessä. (Kettunen 1930: 111; Turunen 1959: 78; Ojansuu 1918: 33; Bubrih, Beljakov \& Punžina 1997: kartta 145.) Etelä-Pohjanmaalta on todennettu osasta aluetta, erityisesti murrealueen länsiosista, myös monikon 2. persoonan alkuperäiset imperfektimuodot tyyppiä saita, veitä (ks. Laurosela 1913: XV, XXI; Rapola 1966: 143), joissa siis odotuksenmukaisesti esiintyy vahva-asteinen persoonapääte pääpainollisen tavun jäljessä. Näitä ei esiinny itämerensuomalaisella kielialueella missään muualla kuin Etelä-Pohjanmaalla. Niitä täytyy siis pitää vähintään kantasuomalaisina, ja niiden voi katsoa kuuluvan vähintään samaan aikatasoon kuin edellä mainitun inessiivin $s n A \sim h n A$-päätteen.

Lounais- ja hämäläismurteissa monikon 1. ja 2. persoonan muodot ovat sekä preesensissä että imperfektissä $m m e$ ja tte. Etelä-Pohjanmaan $m m A, m A$ ja $t t A, t A \sim j A$ eivät siis mitenkään ole rekonstruoitavissa samasta lähtömuodosta näiden kanssa. 
Etelä-Pohjanmaan murteissa esiintyvät päätteet - tai varsinkin monikon 2. persoonan pääte - periytyvät kiistatta varhemmasta kantakielivaiheesta, josta myös savon ja karjalan muodot polveutuvat. Jos edelleen pidämme kiinni pohjoiskantasuomen oletuksesta, jonka mukaan lounais-, hämäläis- ja eteläpohjalaismurteilla on yhteinen lähtömuoto, täytyy olettaa, että Etelä-Pohjanmaa on ollut tästä kantakielivaiheesta kielellisesti eriytynyt jo viimeistään samaan aikaan kuin savolaismurteiden alkukotina pidetty Savilahden seutu - eli noin vuonna 800 jKr. Tämän jälkeen lounais- ja hämäläismurteet ovat jatkaneet erilliskehitystään ja kadottaneet mainitut arkaismit.

Tässä yhteydessä on syytä ottaa puheeksi myös se johdannossa mainitsemamme seikka, että Etelä-Pohjanmaalla monikon 1. ja 2. persoonan persoonapäätteet ovat $A$-loppuisia, kun ne taas lounais- ja hämäläismurteissa ovat yleiskielen tapaan $e$ loppuisia. Lounaismurteissa tosin monikon 1. ja 2. persoonan päätteet ovat usein loppuheittoisia, jolloin loppuvokaalin laatu ei ole enää nähtävissä, esimerkiksi saam $\sim$ saa $(n)$; saat. (Kettunen 1940: kartat 164, 165.) Osassa aluetta tavataan kuitenkin $e$ loppuisiakin variantteja, esimerkiksi tuleme, oleme (Ojansuu 1903: 148), joten loppuheittoiset variantit palautunevat $e$-loppuun. Vanhassa kirjasuomessa tosin esiintyy jonkin verran myös A-loppuisia variantteja (Rapola 1965: 332-333), joten niitä on saatettu aiemmin käyttää myös lounaismurteissa. $A$-loppuisuus koskee kaikkia pohjalaismurteita, savolaismurteita, karjalaa, vepsää, inkeroista ja vatjaa. (Laanest 1975: 150.) Yhteistä pohjoiskantasuomalaista kantaa on siis vaikea olettaa.

Erkki Itkosen jo vuonna 1955 esittämän teorian mukaan $A$-loppuiset päätteet edustavat alkuperäistä monikon persoonapäätettä ja $e$-loppuiset puolestaan olisivat alun perin duaalin päätteitä (1955: 170-171). Pystymättä tässä ottamaan tarkemmin kantaa monikon ja duaalin muinaiseen työnjakoon lienee kuitenkin pakko olettaa, että kyseessä on jälleen maantieteellinen levikki, jonka täytyy olla hyvin vanhaa perua. Huomiota kiinnittää myös se, että e-loppuiset päätteet ovat vallalla lounais- ja hämäläismurteiden lisäksi osin virossa eli itämerensuomalaisen kielialueen ytimessä. Suomen pohjalais- ja savolaismurteissa, karjalassa, vepsässä, vatjassa ja osin virossa puolestaan käytetään pääasiassa varhempia $A$-loppuisia variantteja. Näiden vanhuutta osoittavat paitsi levikin laajuus itämerensuomessa myös vastineet saamessa ja aina marissa asti. (E. Itkonen 1955: 171.)

*ek- ja *eh-nominien erillään säilyminen ei rajoitu niin puhtaasti vain EteläPohjanmaan murteeseen kuin edellä käsiteltyjen piirteiden. Lounaismurteissa * $e k$ - ja *eh-nominit ovat kyllä langenneet täysin yhteen, kuten suomen kielessä yleensäkin, mutta kaakkoishämäläisten murteiden Iitin ryhmässä ne ovat pysyneet erillään. Siellä - $h$ on säilynyt tai toisinaan muuttunut $s: k s i$. Osassa aluetta $-k$ esiintyy $-t$ :nä ja myös vokaalivartalot ovat erilaisia, koska jälkitavun vokaalienvälinen $h$ on säilynyt, esimerkiksi veneh : venehes, mutta päret : päries pärees (Lindén 1942: 37-38, 85, 130-131). Edustus on siis osassa aluetta samanlainen kuin Etelä-Pohjanmaalla. Lindén (mts. 131) arveleekin, että kyseessä saattaa olla geneettinen yhteys.

*ek- ja *eh-nomien edustus on helppo rekonstruoida lounais-, hämäläis- ja eteläpohjalaismurteiden yhteiseen lähtömuotoon. Eteläpohjalaisena arkaismina niiden edustus ei siis ole samalla tavalla yllättävä kuin edellä esiteltyjen piirteiden. Levikki on kuitenkin jälleen huomionarvoinen. ${ }^{\star} e k$ - ja ${ }^{\star} e h$-nominien vokaalivartalot ovat pysy- 
neet erillään osin itäisten savolaismurteiden keski- ja eteläosissa sekä Savonlinnan seudun murteissa (Turunen 1959: 265-267; Palander 1996: 317-318), karjalassa (Ojansuu 1918: 30, 42-44 , 118, 163) ja vepsässä (Tunkelo 1946: 187-188, 286-287).

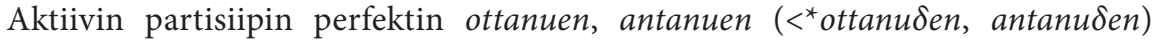
-tyyppiset vokaalivartaloiset muodot, joissa alkuperäinen $U$-e-vokaaliyhtymä on säilynyt, ovat yksi Etelä-Pohjanmaan murteen kiistattomista arkaismeista, joita muissa suomen murteissa ei tavata. Näitä kuitenkin esiintyy vielä 1600-luvulla vanhassa kirjasuomessa (Rapola 1965: 316), joten niiden perusteella ei voi päätellä mitään murteen mahdollisesta rautakautisesta kerroksesta. Mielenkiintoisempia ovat passiivin partisiipin perfektin otettuen-tyyppiset muodot, jotka ovat uniikkeja koko itämerensuomalaisella kielialueella ja joita ei esiinny myöskään vanhassa kirjasuomessa. Muoto edellyttäisi rekonstruktiota * otettuঠen (: otet tut). Virossa, vepsässä ja liivissä passiivin perfektimuodot ovat $t$-loppuisia, mikä antaisi syyn olettaa niiden olevan myöhäiskantasuomalaisia. Kirjallisuudessa on kuitenkin tähän saakka toistuvasti epäilty, että $t$ loppuisuus on analogiaa vastaavista aktiivin partisiipin perfektimuodoista. (Rapola 1966: 46; Laanest 1975: 162-163; Hakulinen 1979: 221.)

Kun pidämme mielessä Etelä-Pohjanmaan edellä mainitut arkaismit, on nähdäksemme mahdollista olettaa otettuen-tyyppisten muotojen puhuvan alkuperäisen $t$-lopun puolesta. Myös Tunkelo (1946) arvelee, että $t$-loppuiset muodot olisivat myöhäiskantasuomalaisia. Perusteluksi hän esittää, että aktiivin partisiipin perfektin muodoista $t$ on vepsässä kadonnut mutta vastaavissa passiivin muodoissa se on edelleen säilyneenä, esimerkiksi otnu : ottud. Jos passiivisten partisiippien loppu- $t$ todella olisi peräisin aktiivin partisiippimuodoista, olisi se varmaan näistäkin hävinnyt. (Mts. 133.) Kyseessä olisi näin jälleen arkaismi, jota ei tavata hämäläis- eikä lounaismurteissa mutta josta on jälkiä kauempana itäisessä itämerensuomessa.

Uniikkeja suomen kielessä ovat myös aktiivin partisiipin perfektin alkuperäiset monikkovartaloiset muodot, joissa näkyy muutos ${ }^{\star} t i>s i$, esimerkiksi tullusia, ottanu-

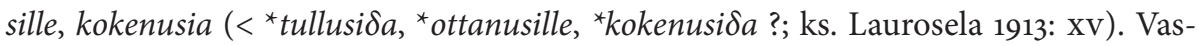
taava muutos näkyy myös Ut-johdoksissa, esimerkiksi kytkysiä (< ${ }^{*} k y t k y s i \delta \ddot{a}$; Aminoff 1871: 16-17). Näissä on myöhäiskantasuomessa esiintynyt alun perin aina $s$ monikon i:n edellä (Rapola 1966: 149). Erikoista on jälleen, että puheena olevan kaltaisista partisiippimuodoista on mainintoja Etelä-Pohjanmaan lisäksi karjalan kielestä, tosin harvinaisina tapauksina. Eteläkarjalaisissa murteissa partisiippien ja Ut-nominien taivutuksessa esiintyy $z$, esimerkiksi miehyt : miehyzien, olluh : olluzien, männyt : männyzie. (Aminoff 1871: 17; Ojansuu 1918: 163, ks. myös s. 31-32.) Partisiippimuotojen lisäksi $U t$-nominien monikkovartaloissa esiintyy sama muutos. Tästä on mainintoja myös vepsästä. Tunkelolla (1946: 124) on esimerkkinä regut : reguden : reguzid (< ${ }^{\star}$ rekusita) 'pikku reki, kelkka'.

Yksi Etelä-Pohjanmaan muissa länsimurteissa tuntemattomista piirteistä on labiaalivokaaliset yksikön 3. persoonan päätteet, esimerkiksi menöö, tuloo, hyppelöö. Nämä eivät sinänsä ole arkaismeja vaan ehkä hyvinkin nuoria kehittymiä (ks. esim. Mielikäinen 1981: 123), mutta asettamalla niiden syntymisen edellytyksenä olevat äänteenmuutokset kronologiseen järjestykseen voidaan jälleen päätellä jotain EteläPohjanmaan murteen vaiheista. Tällaiset labiaalivokaaliset muodot nimittäin edel- 


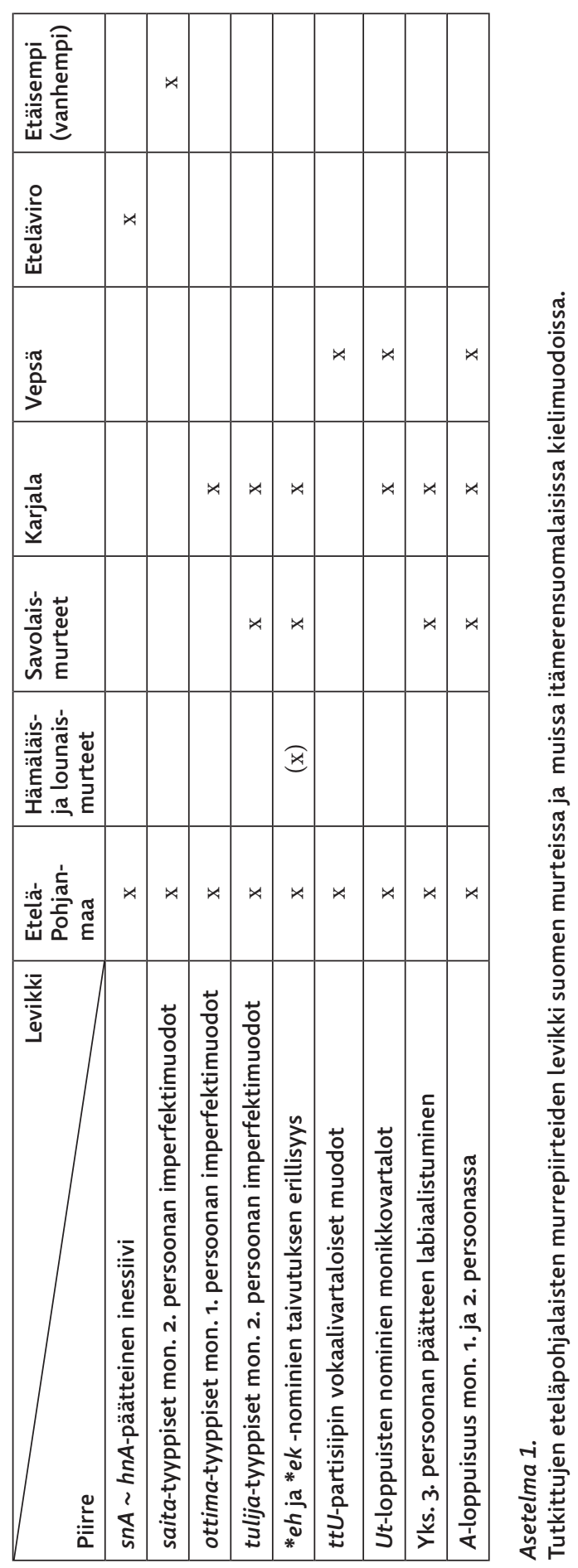


lyttävät rekonstruktiopolkua ${ }^{\star}$ tule $\beta i>{ }^{*}$ tulevi $>{ }^{*}$ tulev $(i)>{ }^{*}$ tulov $(i)>{ }^{*}$ tulou $>$ tuloo. Näissä labiaalispirantti ja sen jatkajat $v$ ja $u$ lienevät vaikuttaneet siihen, että myös vartalon $e$-vokaali on labiaalistunut. Viimeksi mainitut tuloo-tyyppiset muodot ovat käytössä savolaismurteissa, ja karjalassa tavataan niiden lisäksi tulou-tyyppisiä muotoja (Rapola 1966: 170-174; Laanest 1975: 150; Bubrih, Beljakov \& Punžina 1997: kartta 139); joissain murteissa myös $w$-loppuiset asut ovat säilyneet, esimerkiksi lähtenöw (Zajkov 2000: 48). Hämäläis- ja lounaismurteiden tulee-tyyppiset muodot ovat kehittyneet erillään tästä seuraavasti: ${ }^{\star}$ tule $\beta i>{ }^{\star}$ tulevi $>$ tulev $>$ tulee (ks. Ojansuu 1903: 57-58; Lindén 1942: 106), joten Etelä-Pohjanmaan murteen kehityksen lähtötilanteen täytyy palautua sellaiseen aikatasoon, jolloin yksikön 3. persoonassa vielä olivat käytössä päätteet ${ }^{*} p i$ : $\beta i$ (kronologiasta ks. Laurosela 1913: 16-17). Näin tulkittuna labiaalivokaaliset 3. persoonan päätteet kuuluvat niihin eteläpohjalaisuuksiin, joiden levikki on savolaiskarjalainen.

Aikoinaan jo Aminoffin (1871) listaamista eteläpohjalaisista erikoispiirteistä voi siis kootusti todeta, että nykytutkimuksen valossa niistä ainakin kaksi eli $s n A$ $h n A$-inessiivi ja saita-tyyppiset imperfektit palautuvat vähintään myöhäiskantasuomalaiseen rekonstruktiotasoon eikä niille voi ainakaan yksiselitteisesti rekonstruoida hämäläis-lounaista lähtömuotoa. Seitsemän piirrettä eli monikon 1. ja 2. persoonan alkuperäiset imperfektimuodot tyyppiä ottima, tulija, ${ }^{*} e h$ - ja ${ }^{\star} e k$-nominien vokaalivartaloiden edustus, passiivin partisiipin perfektin otettuen-tyyppisen vokaalivartaloiset muodot, kokenusia-tyyppiset partisiippimuodot, yksikön 3. persoonan labiaalivokaaliset päätteet ja monikon 1. ja 2. persoonan verbinmuotojen persoonapäätteiden $A$-loppuisuus ovat eteläpohjalais-savolais-karjalaisia ja osittain myös vepsäläisiä. Niiden on siis mahdollista ajatella polveutuvan siitä rautakautisesta kielimuodosta, joka levisi $800 \mathrm{jKr}$. toisaalta Hämeestä itään ja kohtasi muinaiskarjalaisen kielimuodon ja joka samoihin aikoihin tai jopa vähän ennemmin oli ehtinyt EteläPohjanmaalle Kyrönjoen suun seudulle. Hämäläisiltä ja lounaisilta tiheämpään asutuilta ja ehkä enemmän kontakteja kohdanneilta alueilta nämä piirteet myöhemmin katosivat.

Myöhemmän tutkimuksen tehtäväksi jätämme tässä vielä muutamat muut kielenpiirteet, joilla myös on eteläpohjalais-savolainen levikki ja joihin on Aminoffin lisäksi viitattu muissakin aiemmassa tutkimuksessa. Tällaisia ovat esimerkiksi alkuperäisten ${ }^{\star} o i$-nominien $j:$ lliset yksikön partitiivimuodot ja ${ }^{*} o i$-vartaloisten verbien

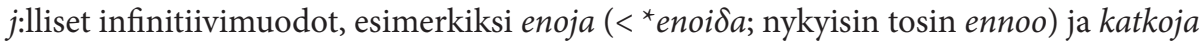

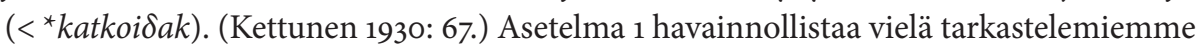
piirteiden levikkiä.

Olemme tässä analysoineet pelkästään äänne- ja muotorakenteeseen kuuluvia seikkoja, mutta myös sanaston levikissä saattaa olla piirteitä, jotka käyvät yksiin edellä esitetyn skenaarion kanssa. Olemme käyneet kokeeksi läpi Itämerensuomalaisen kielikartaston (Atlas Linguarum Fennicarum) kaikki kolme osaa (2004-2010) ja poimineet sanat, joiden levikki on vain tai lähes kokonaan eteläpohjalainen, eteläpohjalaissavolainen tai eteläpohjalais-savolais-karjalainen. Pelkästään eteläpohjalaisia ovat esimerkiksi sanat antura ('reen jalas'), kakku ('karitsa'), karo ('pässi'), kilu ('naarasvuohi, kuttu'), kollain kolli(n)marja ('[musta]herukka, rubus nigrum'), lohna ('iso korireki'), 
luhta ('niitty'), luhdikka ('mesimarja, rubus arcticus'), mera ('tamma') ja mäntä ('hierin, härkin'). Eteläpohjalais-savolaisia tai eteläpohjalais-savolais-karjalaisia ovat esimerkiksi härkä, jotta merkityksessä 'että', imiäinen imiäisheinä ('apila'; myös KaakkoisHäme), kesä, korvo ('saavi'), pulkka ('pieni kapea ajelureki') ja sanko. Myös Leinon, Hyvösen ja Salmenkiven (2006: 39) artikkeli, jossa suomen murteiden rajoja on tarkasteltu sanastopiirteiden levikkien mukaan, osoittaa, että Etelä-Pohjanmaa muodostaa sanastollisesti muista alueista selvästi erillisen murrealueen. Sanaston levikkiseikkojen tarkastelu vaatii kuitenkin oman tarkemman analyysinsa, jonka jätämme tulevan tutkimuksen tehtäväksi.

Seuraavassa luvussa esittelemme arkeologien viimeaikaisia käsityksiä rautakauden asutusliikkeistä ja kielitieteilijöiden näkemyksiä myöhäiskantasuomen leviämisestä Suomenlahden pohjoispuolisilla alueilla. Lopuksi kytkemme nämä käsitykset edellä kuvattujen kielenpiirteiden levikkiin ja historiaan.

\section{Rautakauden asutusliikkeet ja arkaististen piirteiden levikki}

Nykyisen arkeologisen tutkimuksen mukaan Suomen läntiset rannikkoalueet Uudeltamaalta Varsinais-Suomen ja Satakunnan kautta aina Etelä-Pohjanmaalle saakka muodostivat varsin yhtenäisen esineellisen kulttuurin alueen jo esiroomalaisella rautakaudella eli noin vuosina $500 \mathrm{eKr}$.-o jKr. Oletettavasti tämän alueen kulttuuri, niin sanottu Morby-keramiikan vyöhyke, perustui samanlaiseen talousmuotoon, vuorovaikutukseen ja yhteyksiin Itämeren ympäristössä. Laajemmin tarkasteltuna samaan kulttuuripiiriin kuuluivat edellä mainittujen alueiden lisäksi Keski-Ruotsin ja Viron rannikkoseudut. Esineiden ja tavaroiden ohella myös muiden kulttuuripiirteiden, kuten rituaalien, uskomusten ja kielellisten vaikutteiden, uskotaan levinneen tämän alueen piirissä (Edgren 1999: 311-330; Raninen \& Wessman 2015: 223-227). Nykyisin oletetaan, että myöhäiskantasuomi levisi Itämeren alueella juuri tässä vaiheessa ja sitä puhuttiin Suomenlahden molemmin puolin viimeistään vuoden $500 \mathrm{eKr}$. jälkeen. (Häkkinen 2010: 57-58; Kallio 2014: 164.)

Roomalaisella rautakaudella eli noin vuosina o-400 jKr. nykyisen Suomen alueen vauraimmat ja todennäköisesti myös tiheimmin asutut seudut löytyivät LänsiUudeltamaalta Satakuntaan ulottuneelta lounaiselta rannikkovyöhykkeeltä. Asutus sijoittui - samoin kuin edelliselläkin aikakaudella - merenlahtien, jokisuiden ja jokien alajuoksujen rantamille, joten ihmisten elinkeinot perustuivat todennäköisesti merellisten resurssien hyödyntämiseen ja meriyhteyksien kautta käytävään kauppaan. EteläPohjanmaan alue kuului edelleen samaan kulttuuripiiriin eteläisten rannikkoseutujen kanssa, mutta nuoremmalla roomalaisajalla (noin v. 200-400 jKr.) se alkoi eriytyä selvemmin omaksi alueekseen, jossa kehittyi esimerkiksi omia esinemuotoja ja hautaustapoja. (Edgren 1999: 311-330; Raninen \& Wessman 2015: 223-227, 234, 248.)

Etelä-Pohjanmaan asutus oli luultavasti vauraimmillaan suhteessa Etelä-Suomen asutuskeskuksiin kansainvaellusajalla (noin v. 400-575 jKr.). Todisteena tästä ovat suorastaan monumentaaliset, kokonaan kivestä rakennetut kalmistot, joista suurimmat ovat halkaisijaltaan 10-20 metriä. Ne ovat kooltaan poikkeuksellisia Suomen rauta- 
kauden kalmistojen joukossa. Etelä-Pohjanmaan vaurauden perustana lienee ollut laajamittainen turkiskauppa, jonka välittäjinä alueen asukkaat toimivat. Arkeologisten löytöjen perusteella pohjalaisten kontaktiverkosto ulottui tässä vaiheessa hyvin laajalle: idässä Laatokan rannoille, etelässä Kokemäenjoen vesistöalueelle ja pohjoisessa MetsäLappiin asti. Yhteyksiä oli myös Pohjanlahden länsipuolelle. Pohjalaisten rautakaudella käyttämästä kielestä on vain arveluja. Mahdollisina kielinä on esitetty niin suomen, saamen kuin germaanisten kielten varhaisia muotoja (Meinander 1950: 131-132, 153; Huurre 1995: 166-167; Raninen \& Wessman 2015: 234, 248).

Etelä-Suomen kalmistokulttuurin alue Varsinais-Suomessa ja Satakunnan-Hämeen alueella laajeni edelleen merovingiajalla (noin v. 575-80o jKr.). Tiheimmät asutuskeskittymät sijaitsivat samoilla alueilla kuin aiempina vuosisatoina, mutta läntistä tyyppiä edustavia kalmistoja alettiin rakentaa nyt myös Päijät-Hämeessä, Etelä-Savossa ja Karjalankannaksella. Paikannimistössä tälle aikakaudelle ajoitettuja läntisiä yhteyksiä on löytynyt aina Peräpohjolaa eli Tornionjoki- ja Kemijokilaaksoa myöten. Tämä merkitsi vähintään kulttuurivaikutteiden mutta todennäköisesti myös asutuksen leviämistä rannikolta sisämaahan, lännestä itään ja etelästä pohjoiseen. Syynä oli ehkä läntisten asutuskeskusten nopea väestönkasvu, joka purkautui uudisasutuksena väljemmille seuduille. (Vahtola 1980: 513-514; Huurre 1995: 169-170; Raninen \& Wessman 2015: 265-266.)

Poikkeuksen edellä kuvattuun laajenevaan kehitykseen muodosti Etelä-Pohjanmaa, jossa kalmistot päinvastoin vähenivät ja köyhtyivät esineistöltään. Sama kehitys jatkui siellä viikinkiajalla (noin v. 80o-110o jKr.), eikä alueelta ole löydetty yhtään 80o-luvun alkupuoliskoa nuorempaa kalmistoa. Myös tutkitut asuinpaikat näyttäisivät tyhjentyneen viikinkiajan lopulle tultaessa. Vanhastaan tätä on pidetty osoituksena alueen autioitumisesta viikinkiajalla. (Meinander 1950: 151-152; Lehtosalo-Hilander 1985: 311; Huurre 1995: 168; Raninen \& Wessman 2015: 307.) Kartta 1 (ks. seur. sivua) havainnollistaa rautakauden lopun asutusta ja sen leviämistä.

Kuten edellä olemme tuoneet esiin, nykyisten tutkimusten perusteella EteläPohjanmaan täydellistä autioitumista ei enää pidetä todennäköisenä. Esimerkiksi siitepölyanalyysien perusteella on todettu, että Etelä-Pohjanmaan rannikolla viljeltiin maata vielä kalmistokulttuurin häviämisen jälkeen. On kuitenkin selvää, että asutus heikkeni ja köyhtyi. Entisenlaisia suuria kalmistoja ei enää rakennettu, ja asutus siirtyi uusille alueille. Syitä asutuksen ja talouden kriisiin on haettu sodista ja ruttoepidemiasta lähtien, mutta syyt voivat olla arkisempiakin. Todennäköisesti alue jäi paitsioon turkiskaupasta, josta se oli aiemmin hyötynyt. Tähän saattoi vaikuttaa rannansiirtymä, joka muutti ympäristöoloja, kuten purjehdusmahdollisuuksia, ja haittasi myös maanviljelystä, kun rehevät rantaniityt vähenivät. Seurauksena oli talouden ja väestön taantuma. (Baudou, Engelmark, Liedgren, Sedeström, \& Wallin 1991: 205207; Kuusela ym. 2011: 188-190; Kuusela 2013: 6, 153-154; Raninen \& Wessman 2015: 307-308; vrt. Meinander 1950: 153-155; Huurre 1995: 168.)

Tällä hetkellä uskotaan, että myöhäiskantasuomesta eronnut kielimuoto eli pohjoiskantasuomi (Jaakko Häkkisen "muinaishäme") levisi Etelä-Pohjanmaalle ensimmäisen vuosituhannen jälkipuoliskolla. Tätä ennen alueella puhuttiin mahdollisesti saamea ("eteläsaamelaista muinaismurretta"), joskaan tätä ei ole pitävästi todistettu. (Häkkinen 


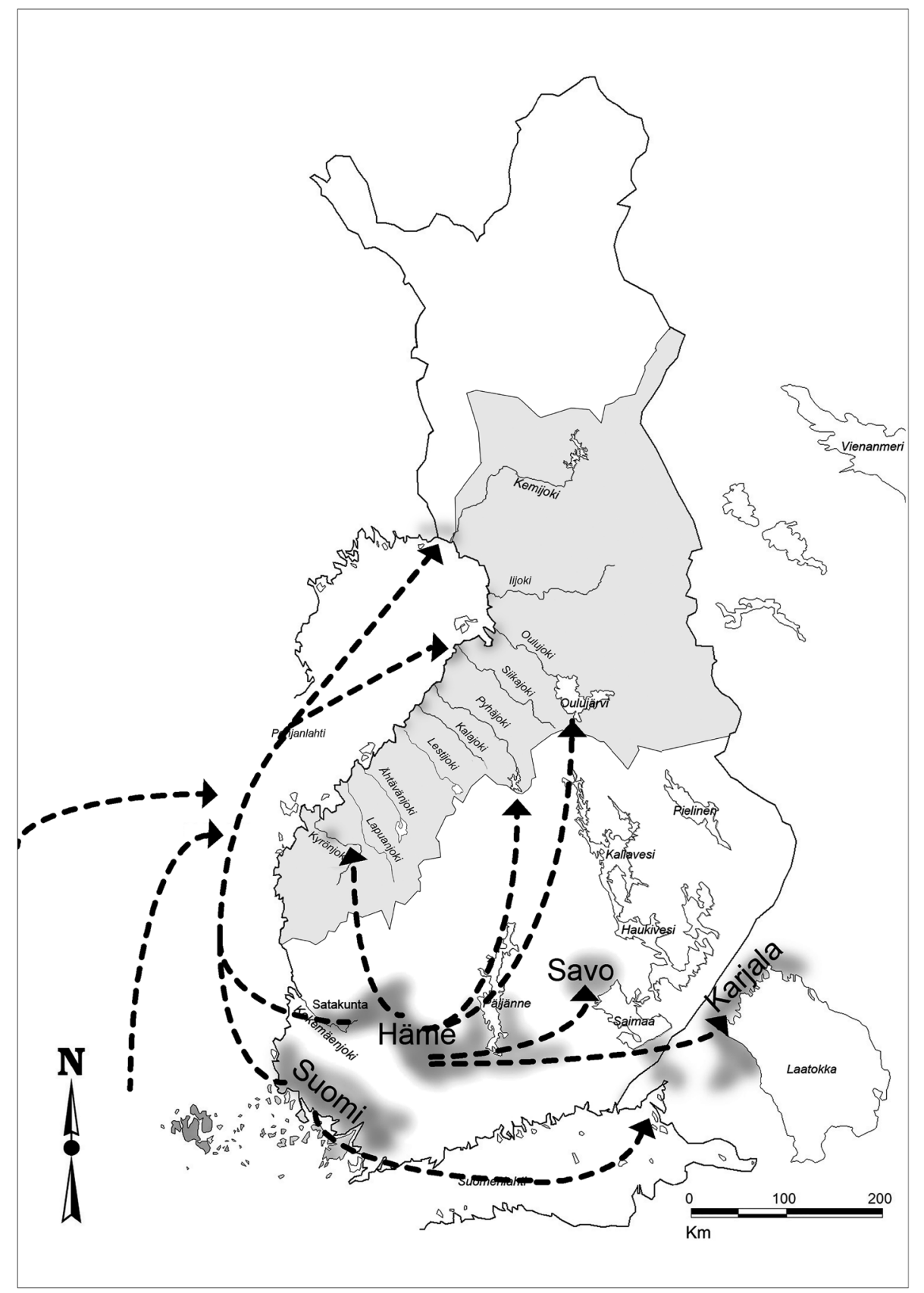

Kartta 1.

Asutus ja väestöliikkeet rautakauden lopulla (noin 800-1100 jKr.). Kalmistolöytöjen perusteella tiheimmin asutut alueet on tummennettu ja Pohjanmaan maakunta on merkitty vaaleanharmaalla. (Kartta: Matti Leiviskä.) 
2010: 59-61; vrt. Saarikivi \& Frog 2014: 97-98.) Joka tapauksessa siirtymä alueella aiemmin puhutusta kielestä pohjoiskantasuomeen tapahtui vähän ennen tai juuri samoihin aikoihin, kun alue vajosi taantumaan ja entiset laajat kontaktiverkostot surkastuivat. Tämä tarkoitti myös ulkoisten vaikutteiden heikentymistä, mikä selittäisi hyvin sen, että muutamat kielen arkaistiset piirteet säilyivät Etelä-Pohjanmaalla, kun ne muualta hävisivät.

\section{Lopuksi}

Jo 180o-luvulta lähtien fennistisessä kirjallisuudessa on kommentoitu Etelä-Pohjanmaan murteen sisältävän arkaistisia piirteitä. Tässä artikkelissa olemme osoittaneet, että koska muutamat samat kielelliset reliktit tavataan Etelä-Pohjanmaalla, savolaismurteissa, karjalassa, osin jopa vepsässä muttei hämäläis- ja lounaismurteissa, on tehtävä päätelmä, että nämä periytyvät sellaisesta kantakielivaiheesta, jossa mainitut kielimuodot eivät vielä olleet eriytyneet, eli pohjoiskantasuomesta. Etelä-Pohjanmaan murteen eriytyminen olisi siis tämän mukaisesti sijoitettava jo viikinkiajalle (noin v. 80o1100 jKr.), samaan aikatasoon, jolloin savo erkaantui muinaiskarjalasta. Savoon ja Laatokan seudulle ylsi tuolloin hämäläisvaikutus, joka paitsi toi muinaissavoon hämäläisen komponentin myös aiheutti karjalan ja vepsän eriytymisen. Samaan aikaan asutus ja pohjoiskantasuomalainen kielimuoto siis ylsivät Etelä-Pohjanmaalle, jossa saman kantakielivaiheen samankaltaiset jäljet edelleen näkyvät. Tiheämmin asutuilla rintamailla Lounais-Suomessa ja Hämeessä nämä piirteet katosivat tai ne säilyivät osittain joillain perifeerisillä alueilla. Kaksi kielenpiirrettä eli $\operatorname{snA} \sim h n A$-päätteinen inessiivi ja monikon 2. persoonan imperfektin $t A$-päätteiset verbinmuodot puolestaan ovat vieläkin vanhempia ja edellyttävät vähintään myöhäiskantasuomalaista rekonstruktiotasoa.

Tiettyjen arkaististen kielenpiirteiden levikin ja historian pohjalta luomamme skenaario rautakauden loppupuolen (noin v. 800-1100 jKr.) tilanteesta sopii hyvin yhteen kartan 1 kanssa, jossa rautakauden väestöliikkeet on kuvattu kootusti. Kartassa näkyvät länsisuomalaiset asutuskeskukset Varsinais-Suomi ja Satakunta-Häme. Viimeksi mainitusta on suuntautunut väestöliike Savoon, Laatokan-Karjalaan ja EteläPohjanmaalle. Sopii ajatella, että kuvatussa aikatasossa sama kielimuoto levisi mainituille alueille ja yhteisen, samaan aikatasoon palautuvan kantakielen piirteitä esiintyy myöhemmin murteissa, jotka muutoin ovat kokeneet myöhempiä muutoksia ja eriytyneet kovastikin toisistaan. Näin Etelä-Pohjanmaan murteen erikoiset arkaismit, jotka ovat lisäksi yhteisiä itäisten itämerensuomalaisten kielimuotojen kanssa, saisivat loogisen selityksen.

Lopuksi on vielä todettava, että edellä esittämämme ei lopullisesti todista mitään Etelä-Pohjanmaan murteen rautakautisesta kerrostumasta. Edelleen on uskaliasta rinnastaa arkeologien käsityksiä myöhäisen rautakauden asutuksesta myöhempien aikojen kielenpiirteiden levikkiin. Lopulta artikkelimme päähavainto tiivistyykin siihen, että kielitiede ei aseta rajoituksia ajatukselle, että Etelä-Pohjanmaan asutus olisi jatkunut katkeamattomana läpi rautakauden vaan päinvastoin tukee sitä. Toisinpäin ajateltuna arkeologian viimeaikaiset näkemykset antavat fennisteille luvan olettaa, että 
rautakaudella puhutun pohjoiskantasuomalaisen kielimuodon jälkiä näkyy maakunnan murteessa.

\section{Lähteet}

Aminoff, Torsten Gustav 1871: Etelä-Pohjanmaan kielimurteesta. Tutkimus. Helsinki: Suomen Aleksanterin-yliopisto.

Atlas Linguarun Fennicarum. Itämerensuomalainen kielikartasto. Osat 1-3. Tuomo Tuomi (päätoim.). Helsinki: SKS \& Kotimaisten kielten tutkimuskeskus 2004, 2006 ja 2010.

Baudou, Evert - Engelmark, Roger - Liedgren, Lars - Segerström, Ulf WALLIN, JAN-ERIK 1991: Järnåldersbygd i Österbotten. En ekologisk-arkeologisk studie av bosättningskontinuitet och resultutnyttjande. Vasa: Scriptum.

Bubrih, D. V. - Beljakov, A. A. - Punžına, A. V. 1997: Karjalan kielen murrekartasto. Toimittanut Leena Sarvas. Helsinki: Suomalais-Ugrilainen Seura.

Edgren, Torsten 1999: Alkavan rautakauden kulttuurikuva Länsi-Suomessa. - Paul Fogelberg (toim.), Pohjan poluilla. Suomalaisten juuret nykytutkimuksen mukaan s. 311-333. Helsinki: Suomen Tiedeseura.

Hakulinen, LaURi 1979: Suomen kielen rakenne ja kehitys. 4., korjattu painos. Helsinki: Otava.

Hu rre, Matti 1995: 9000 vuotta Suomen esihistoriaa. Helsinki: Otava.

НӒкKINEN, JА А ко 2010: Jatkuvuusperustelut ja saamelaisen kielen leviäminen. Osa 2. - Muinaistutkija 2/2010 s. 51-64.

ITKONEN, ERKKI 1955: Onko itämerensuomessa jälkiä duaalista? - Virittäjä 59 s. 161-175.

It konen, Terho 1972: Historiantakaiset Häme ja Suomi kielentutkijan näkökulmasta. - Historiallinen aikakauskirja 70 s. 85-112.

— 1983: Välikatsaus suomen kielen juuriin. - Virittäjä 87 s. 349-386.

— 1984: Suomessa puhutun suomen kantasuomalaiset juuret. - Suomen väestön esihistorialliset juuret. Tvärminnen symposiumi 17-19.1.1980. Helsinki: Suomen Tiedeseura.

Kallio, Petri 2014: The diversification of Proto-Finnic. - Joonas Ahola, Frog \& Clive Tolley (toim.), Fibula, fabula, fact. The viking age in Finland s. 155-168. Helsinki: SKS.

Kettunen, Lauri 1930: Suomen murteet II. Murrealueet. Helsinki: SKS.

— 1940: Suomen murteet III A. Murrekartasto. Helsinki: SKS.

Ku usela, JARI-Matti 2013: Political economy of bronze-and iron age societies in the eastern coast of the bothnian bay ca. 1500 BC - AD 1300. Oulu: Oulun yliopisto.

Kuusela, Jari-Matti - Timlikkala, Jasse - Vaske, Riku-Ville - Okкonen, Jari 2011: Keskus-periferiamalli Pohjois-Suomen rautakauden asutusdynamiikan tarkastelun apuna. - Faravid 35 s. 177-204. Rovaniemi: Pohjois-Suomen historiallinen yhdistys.

LaAnest, Arvo 1975: Sissejuhatus läänemeresoome keeltesse. Tallinn: Eesti NSV Teaduste Akadeemia Keele ja Kirjanduse Instituut.

Laurosela, Jussi 1913: Ä̈nnehistoriallinen tutkimus Etelä-Pohjanmaan kielimurteesta I. Konsonantit. Helsinki: SKS.

Lehtinen, TAPAni 2007: Kielen vuosituhannet. Suomen kielen kehitys kantauralista varhaissuomeen. Tietolipas 215. Helsinki: SKS.

LehtosAlo-Hilander, Pirkko 1985: Keski- ja myöhäisrautakausi. - Eero Laaksonen, Erkki Pärssinen \& Kari J. Sillanpää (toim.), Suomen historia 1 s. 253-403. Espoo: Weilin \& Göös.

Leino, Antti - Hyvönen, SaAra - Salmenkivi, Marko 2006: Mitä murteita suomessa 
onkaan? Murresanaston levikin kvantitatiivista analyysia. - Virittäjä 11o s. 26-45.

Leiviskä, Matti 2015: Asutusvirrat Pohjanmaalle keskiajalta 160o-luvulle. - Markku Mattila (toim.), Aina liikkeessä. Liikkuvainen Pohjanmaa s. 8-28. Aluekeskuksen tutkimuksia 7. Turku: Siirtolaisuusinstituutti.

Leskinen, Heik i 1999: Suomen murteiden synty. - Paul Fogelberg (toim.), Pohjan poluilla. Suomalaisten juuret nykytutkimuksen mukaan s. 358-371. Helsinki: Suomen Tiedeseura.

LindéN, Eeva 1942: Kaakkois-Hämeen murteiden äännehistoria I. Konsonantisto. Helsinki: SKS.

Luuk кo, Armas 1950: Etelä-Pohjanmaan historia II. Keskiaika ja 15oo-luku. Etelä-Pohjanmaan historiatoimikunta.

Meinander, CARL 1950: Etelä-Pohjanmaan historia I. Esihistoria. Etelä-Pohjanmaan historiatoimikunta.

MieliKäInen, Aila 1981: Eteläsavolaisten murteiden äännehistoria I. Konsonantit. Helsinki: SKS.

OjansuU, Heikki 1903: Suomen lounaismurteiden äännehistoria. Konsonantit. Helsinki: SKS.

— 1918: Karjala-aunuksen äännehistoria. Helsinki: SKS.

Palander, Marjatta 1996: Vaihtelu Savonlinnan seudun välimurteissa. Helsinki: SKS.

Рё̈̈ккӧNen, Матті 1971: Oulun seudun murteen äännehistoria I. Sanansisäiset klusiilit astevaihtelusuhteineen. Helsinki: SKS.

Raninen, Sami - Wessman, Anna 2015: Rautakausi. - Georg Haggrén, Petri Halinen, Mika Lavento, Sami Raninen \& Anna Wessman, Muinaisuutemme jäljet. Suomen esi- ja varhaishistoria kivikaudelta keskiajalle s. 215-368. Helsinki: Gaudeamus.

RaPOla, MART TI 1965: Suomen kirjakielen historia pääpiirteittäin I. Vanhan kirjasuomen kirjoitus- ja äänneasun kehitys. Helsinki: SKS.

— 1966: Suomen kielen äännehistorian luennot. Helsinki: SKS.

SaArikivi, Janne - Frog 2014: De situ linguarum fennicarum aetatis ferreae. Pars I. - Frog, Helen F. Leslie-Jakobsen \& Joseph S. Hopkins (toim.), The Retrospective Methods Network Newsletter 9 s. 64-115. Helsinki: Helsingin yliopisto.

Sammallahti, Pekka 1977: Suomalaisten esihistorian kysymyksiä. - Virittäjä 81 s. 119-136.

SKS = Suomalaisen Kirjallisuuden Seura.

TunkeLO, E. A. 1946: Vepsän kielen äännehistoria. Helsinki: SKS.

Turunen, Aimo 1959: Itäisten savolaismurteiden äännehistoria. Helsinki: SKS.

Vанто LA, Jou ко 1980: Tornionjoki- ja Kemijokilaakson asutuksen synty. Nimistötieteellinen ja historiallinen tutkimus. Studia Historica Septentrionalia 3. Rovaniemi: Pohjois-Suomen Historiallinen Yhdistys.

Zajкov, P. M. 200o: Glagol v karelskom jazike. Petrozavodsk: Petrozavodskij gosudarstvennij universitet. 


\section{Iron-Age evidence in the Southern Ostrobothnian dialect of Finnish}

It has long been recognised within the field of Fennistic research that the Southern Ostrobothnian dialect contains archaic features that are unknown in other western Finnish dialects. In this article, the writers analyse the spread and history of nine such features in the light of recent archaeological research. One significant finding is that many of these features are already familiar from the dialects of Savo, the Karelian language and even Vepsian. Examples of common features found in the dialects of Southern Ostrobothnia and Savo, as well as in Karelian, are original $2^{\text {nd }}$ person plural imperfect forms such as otti(j)a ('you took'). One common feature of Vepsian is a plural stem with -si for Ut nouns such as neittysillen ('to the maids') and the Vepsian regusid (plural partitive for 'sleigh'). The inessive ending $s n A \sim h n A$ is known only in South Estonian, and $2^{\text {nd }}$ person plural verb forms such as saita ('you got') are not known at all in Finnic. It appears, therefore, that these two features are even older, and seem to descend from late Proto-Finnic or earlier still.

This article compares the spread and history of the features analysed to the view of contemporary archaeological scholarship, which contends that by the end of the Iron Age the influence of Northern Proto-Finnic or Ancient Häme (Tavastian) had reached Southern Ostrobothnia, the region of Mikkeli in Savo, ancient Karelian areas and even all the way to Vepsian-speaking regions. Accordingly, the archaic features of the Southern Ostrobothnian dialect would have descended from the same phase of the proto-language and are thus an indication of remnant Iron-Age layers in the dialect.

It has long been known that settlements were common throughout Southern Ostrobothnia from the beginning of the Iron Age (500 BC). However, it has previously been thought that these settlements were destroyed during the Viking period in approximately the $8^{\text {th }}$ century, and it was assumed that the local dialect was created in the first centuries after the year 1000 as a result of new settlements arriving from Häme (Tavastia) and Southwest Finland. However, it is now widely accepted that, though they were greatly impoverished, settlements in Southern Ostrobothnia existed throughout the Iron Age. The primary observation of this article is that present archaeological evidence allows scholars to view the aforementioned archaic features as relics of a language form which spread to Southern Ostrobothnia during the Iron Age. Similarly, the writers contend that Fennistics can now support the archaeological view regarding the continuity of Southern Ostrobothnian settlements throughout the Iron Age. 


\section{Onko Etelä-Pohjanmaan murteessa rautakautisia jälkiä?}

On vanhastaan tunnettua, että Etelä-Pohjanmaan murteessa esiintyy arkaismeja, jotka ovat vieraita muille suomen länsimurteille. Tässä artikkelissa analysoidaan yhdeksän arkaistisen eteläpohjalaisen piirteen levikkiä ja historiaa ja suhteutetaan niitä tämänhetkiseen arkeologiseen tietoon Etelä-Pohjanmaan asutuksesta. Tulos on, että useat näistä piirteistä ovat tunnettuja savolaismurteissa, karjalan kielessä ja jopa vepsässä. Eteläpohjalais-savolais-karjalaisia yhteisiä piirteitä ovat esimerkiksi otti(j)a-tyyppiset monikon 2. persoonan alkuperäiset imperfektimuodot. Vepsään saakka ulottuvat $U t$ nominien si-aineksiset monikkovartalot, esimerkiksi neittysillen, vepsän regusid ('kelkkoja'). Murteen $s n A \sim h n A$-päätteinen inessiivi on tunnettu vain etelävirossa, ja saitatyyppiset monikon 2. persoonan verbinmuodot ovat itämerensuomalaisella kielialueella tuntemattomia. Nämä kaksi piirrettä ovat siis ilmeisesti vieläkin vanhempia ja näyttäisivät edellyttävän myöhäiskantasuomalaista tai jopa vanhempaa kantakielivaihetta.

Tutkittujen piirteiden levikki- ja historiatietoja verrataan artikkelissa arkeologien nykynäkemyksiin, joiden mukaan pohjoiskantasuomalainen tai muinaishämäläinen vaikutus ylsi rautakauden lopussa Etelä-Pohjanmaalle, Savoon Mikkelin seudulle sekä muinaiskarjalaisille alueille - jopa vepsään saakka. Tämän ajattelun mukaan EteläPohjanmaan murteen arkaistiset piirteet periytyisivät tästä samasta kantakielivaiheesta ja kertoisivat murteen rautakautisesta kerrostumasta.

Etelä-Pohjanmaalla on vanhastaan tiedetty olleen vahva asutus jo rautakauden alussa (50o eKr.). Sen on kuitenkin ajateltu tuhoutuneen viikinkiaikaan eli noin vuoteen $800 \mathrm{jKr}$. mennessä, ja alueen murteen on oletettu syntyneen 10oo-luvun ensimmäisinä vuosisatoina Hämeestä ja Varsinais-Suomesta tulleen uuden asutuksen myötä. Nykyisin ajatellaan, että Etelä-Pohjanmaan asutus säilyi rautakauden läpi, joskin köyhtyneenä. Artikkelin päähuomio on, että arkeologian nykytulokset mahdollistavat sen tulkinnan, että mainitut arkaismit ovat jo rautakaudella Etelä-Pohjanmaalle levinneen kielimuodon reliktejä. Samoin voidaan ajatella, että kielitiede tukee arkeologien näkemystä Etelä-Pohjanmaan asutuksen jatkuvuudesta läpi rautakauden.

Kirjoittajien yhteystiedot (addresses):

etunimi.sukunimi@oulu.fi 